\title{
Analisis Keefektifan Pembelajaran Matematika Online
}

\author{
Qurrota A'yun'), Dimas Anditha Cahyo Sujiwo' ${ }^{2}$ \\ ${ }^{1)}$ Universitas Muhammadiyah Jember, Indonesia \\ ${ }^{2)}$ IKIP PGRI Jember, Indonesia
}

Email: qurrota.ayun@unmuhjember.ac.id, cahyodimas10@gmail.com

\begin{abstract}
The purpose of this study was to determine the effectiveness of online mathematics learning, the advantages and disadvantages of online mathematics learning at MTs. Nurul Jadid. This research uses descriptive research with a qualitative approach. Qualitative research is research that describes in detail both the conditions and the process of its implementation, and links the related relationships in the form of findings to research implementation activities. This qualitative research is used to understand all actions on the subject and object under study through qualitative research techniques such as in-depth interviews and student responses to online mathematics learning. Online mathematics learning at MTs. Nurul Jadid is said to be quite effective with the following research results. 1) Online learning activities at MTs. Nurul Jadid in the form of providing materials, giving assignments and collecting assignments. Of course, the impact of this change in teaching and learning is a big loss for teachers because in teaching and learning it becomes less than optimal. However, in terms of online learning activities students are actively involved in the learning process. This also happens to students who were previously inactive during face-to-face learning activities, but in online learning this is active. 2) The percentage of student responses to online learning reaches $68.23 \%$. This value is in the strong category, meaning that students are very happy and enthusiastic about online learning carried out at MTs. Nurul Jadid. 3) Based on the advantages of online learning, students who are quiet or shy are more confident. This can be due to the fact that students are more courageous because they are dealing with teachers and friends through cellphones. The dependence of students on teachers is reduced, students can also find information from various internet sources. Meanwhile, based on the shortcomings, the signal becomes the obstacle for most of the students.
\end{abstract}

Keywords : Effectiveness, Online Learning, Mathematics Learning 


\begin{abstract}
ABSTRAK
Tujuan penelitian ini adalah untuk mengetahui keefektifan pembelajaran matematika online, kelebihan dan kekurangan pembelajaran matematika online di MTs. Nurul Jadid. Penelitian ini menggunakan jenis penelitian deskriptif dengan pendekatan kualitatif. Penelitian kualitatif merupakan penelitian yang menggambarkan secara rinci baik kondisi maupu proses pelaksanaannya, serta mengaitkan hubungannya terkait berupa temuan pada kegiatan pelaksanaan penelitian. Digunakannya penelitian kualitatif ini untuk memahami segala tindakantindakan pada subjek dan objek yang diteliti melalui teknik-teknik penelitian kualitatif seperti wawancara secara mendalam dan respon siswa terhadap pembelajaran matematika online. Pembelajaran matematika online di MTs. Nurul Jadid dikatakan cukup efektif dengan hasil penelitian sebagai berikut. 1) Kegiatan pembelajaran online di MTs. Nurul Jadid berupa pemberian materi, pemberian tugas dan pengumpulan tugas. Tentu dengan adanya dampak perubahan belajar mengajar ini menjadi kerugian besar bagi guru karena dalam belajar menggajarnya menjadi kurang maksimal. Namun dalam hal kegiatan pembelajaran online siswa aktif terlibat dalam proses belajar. Hal ini juga terjadi pada siswa yang sebelumnya tidak aktif pada saat kegiatan belajar secara tatap muka, namun pada pembelajaran online ini aktif. 2) Persentase respon siswa terhadap pembelajaran online mencapai 68,23\%. Nilai ini berada pada kategori kuat artinya siswa sangat senang dan antusias dengan pembelajaran online yang dilaksanakan di MTs. Nurul Jadid. 3) Berdasarkan kelebihan pembelajaran online, siswa yang pendiam atau pemalu lebih percaya diri. hal ini dapat disebabkan karena siswa lebih berani karena berhadapan dengan guru dan teman-temannya melalui media handphone. Ketergantungan siswa pada guru berkurang, siswa juga dapat menemukan informasi dari berbagai sumber internet. Sementara berdasarkan kekurangannya, sinyal menjadi kendalan sebagian besar siswa.
\end{abstract}

Kata Kunci : Efektivitas, Pembelajaran Online, Pembelajaran Matematika

\title{
PENDAHULUAN
}

Teknologi telah berkembang begitu pesat di era globalisasi ini tentu telah memberikan angin segar bagi seluruh sektor. Kemajuan dan kemanfaatannya telah memberikan banyak dampak positif di berbagai aspek. Dalam setiap aktivitas yang telah dilakukan oleh masyarakat tidak dapat dipungkiri teknologi selalu menjadi bantuan yang tak ternilai. Di dunia nyata aplikasi dari teknologi telah dirasakan oleh manusia begitu bermanfaatannya teknologi ini. Kemajuan teknologi dapat dikatakan sebagai keberkahan seluruh kalangan manusia, karena segala pekerjaan ini dapat diselesaikan dengan bantuan teknologi. Teknologi merupakan sebuah pembaharuan yang memiliki nilai tinggi dengan begitu banyak manfaat dan mudah penggunaannya. 
Adaptasi manusia dengan suatu teknologi baru yang telah berkembang begitu pesat harus dilakukan sedini mungkin. Tentu dalam proses adaptasi kita membutuhkan waktu yang tidak dapat kita tebak waktu yang harus diperlukan. Namun kita perlu mempelajarinya dan mengenalkannya kepada generasi muda, terutama manfaat yang begitu besar pada teknologi ini. Upaya-upaya tersebut tentu diharapkan menjadi daya tarik bagi pemuda penerus bangsa agar dapat mengenal setiap teknologi yang baru diciptkan. Setiap teknologi yang berkembang maka akan berdampak pada segala sektor dengan segala keuntungan yang memiliki kemudahan. Ssalah satu sektor yang ketiban dari teknologi adalah sektor pendidikan yag menjadi wadah para siswa delam mengembangan seluruh kemampunnya.

Pendidikan memiliki peranan yang sangat besar dalam meningkatkan potensi manusia. Pendidikan terjadi pada manusia sepanjang hidupnya. Pengalaman hidup yang tertata akan membangun dan mengembangkan segala potensi manusia itu sendiri. Aktivitas lingkungan yang positif tentu akan membawa dampak yang baik bagi manusia itu sendiri. Oleh karenanya pendidikan harus selalu berada di bagian kehidupan manusia, sehingga dapat mengembangkan pribadi yang sebaik-baiknya dan menjadi seumber daya manusia yang unggul kualitasnya.

Kemajuan suatu lembaga pendidikan adalah bagaimana lembaga sekolah mengikuti perubahan globalisasi yaitu memanfaatkan teknologi dan komunikasi secara maksimal. Pembelajaran daring merupakan salah satu kemajuan teknolgi. Pembelajaran online (daring) adalah suatu kegiatan belajar tanpa bertatap muka, namun proses pembelajarannya dilakukan menggunakan bantuan aplikasi atau software yang mudah digunakan oleh guru dengan siswa. Pembelajaran online ini memudahkan penggunanya untuk melakukan kegiatan belajar dengan kualitas mutu yang baik yang dapat menjangkau lebih banyak siswa.

Dalam mendukung pelaksanaan pembelajaran secara daring, pemerintah telah melakukan bantuan dengan memberikan kuota pembelajaran pada seluruh akedimisi termasuk siswa. Dengan adanya bantuan pemerntah ini, siswa dapat melaksanakan kegiatan pembelajaran daring menggunakan berbagai aplikasi pembelajaran. Aplikasi yang dapat dimanfaatkan dan digunakan dalam menunjang proses belajar yaitu WhatsApp (So, 2016), serta Edmodo dan Google Classroom (Enriquez, 2014; Iftakhar, 2016; Sicat, 2015;), Instagram \& Facebook (Kumar and 
Nanda, 2018). Pembelajaran daring adalah pembelajaran yang memenuhi kebutuhan siswa yang didukung oleh berbagai teknologi. Tidak dapat dipungkiri teknologi ini merupakan produk yang digunakan sekarang dan untuk masa depan. Penelitian ini untuk menggambarkan efektivitas pembelajaran online di MTs. Nurul Jadid semasa pandemi covid-19.

Pembelajaran online ini masih jarang dilakukan di sekolah. Sehingga sekolah perlu beradaptasi dengan kegiatan ini di kondisi wabah covid. Salah satunya di MTs. Nurul Jadid Bondowoso yang baru pertama kali kegiatan pembelajarannya berbasis daring/online. Terlebih terkendala wabah virus, seluruh sekolah diwajibkan menggunakan belajar online. Pastinya akan menemui berbagai permalahan dalam kegiatannya, kendala yang paling menonjol berupa kebiasaan siswa yang pertama kali dalam kegiatan belajar online, awalnya tentu akan baik dan antusias karena kegiatannya berbeda dengan sebelumnya, namun dalam perjalanannya siswa akan jenuh juga dampak dari pembelajaran yang sama. Guru sebagai pengelola pembelajaran diharapkan melakukan terobosan atau kreativitas dalam pembelajaran online agar siswa selalu bersemangat dalam belajarnya.

Melalui pembelajaran daring dengan penggunaan berbagai aplikasi atau jaringan siswa akan memperoleh berbagai kemudahan seperti dapat dengan mudah berdiskusi dengan guru dan temannya, mencari berbagai informasi serta dapat mengerjakan tugas dengan mudah. Pembelajaran daring telah digunakan dalam berbagai kegiatan pendidikan, hal ini menunjukkan penerapan teknologi telah menjadi bagian dari berbagai aspek pendiidikan. Pembelajaran daring juga telah menjadi bagian pembelajaran di sekolah, akan tetapi penerapan pembelajaran daring belum maksimal. Dengan uraian tersebut tentu perlu dianalisis Efektivitas dari Pembelajaran Online dalam Pembelajaran Matematika di MTs. Nurul Jadid.

Efektivitas merupakan suatu tingkat keberhasilan seseorang ataupun organisasi yang dilakuakan dengan cara-cara terntentu dalam mencapai tujuan-tujuan atau rencana-rencana tertentu yang ditetapkan. Semakin banyak rencana/tujuan tertentu berhasiltercapai, maka suatu kegiatan tersebut dapat dianggap semakin efektif. Efektivas dapat diartikan sebagai segala usaha yang dilakukan oleh seseorang secara maksimal untuk mencapai terget atau tujuan yang ditentukan atau diharapkan. Segala usaha perlu dilakukan secara maksimal, agar segala aktivitas pekerjaan yang 
telah dikakukan tidak terbuang sia-sia. Dengan pencapaian maksimal rencanarencana yang telah ditetapkan sebelumnya, maka keefektivannya semaking tinggi pula.

Slavin (2019) menyebutkan ada beberapa poin dalam mengukur keefektifan pembelajaran yaitu: 1. Kualitas Pembelajaran, seberapa jauh informasi yang diuraikan sehingga siswa dapat mempelajarinya dengan tingkat kesalahan kecil; 2. Kesesuaian tingkat pembelajaran, sejauh mana guru membawa siswa siap mempelajari materi yang baru; 3. Insentif, seberapa besar usaha memberikan motivasi kepada siswa untuk menyelesaikan tugas belajar dan mempelajari materi yang diberikan; 4. Waktu, dilihat dari banyak waktu yang diberikan kepada peserta didik untuk mempelajari materi yang disampaikan. Selanjutnya Mandagi \& Degeng (2019: 124) keefektifan pembelajaran biasanya diukur dengan tingkat pencapaian sibelajar. Adapun beberapa aspek penting yang dapat dipakai untuk mempreskripsikan keefektifan pembelajaran yaitu: (1) kecermatan penguasaan perilaku yang dipelajari, (2) kecepatan unjuk kerja, (3) tingkat alih belajar, (4) tingkat retensi dari apa yang dipelajari. Dengan demikian kriteria keefektivan dalam penelitian ini adalah apabila aspek berikut ini tercapai: 1. Pengelolaan pembelajaran online baik dan berjalan dengan lancar; (2) aktivitas siswa dalam pembelajaran online berjalan baik; 3. Respon siswa terhadap pembelajaran online baik.

\section{METODE PENELITIAN}

Teknik analisis deskriptif merupakan metode penelitian ini dan jenisnya menggunakan penelitian kualitatif. Sutopo (2006 : 179) menjelaskan bahwa penelitian kualitatif adalah menggambarkan secara rinci baik kondisi maupu proses, serta mengaitkan hubungannya terkait temuan pada kegiatan pelaksanaan. Sementara Bogdan and Taylor (dalam Moleong, 2014 : 4) merupakan penelitian yang mengambarkan pelaskanaan dengan kata. Digunakannya penelitian kualitatif ini untuk dapat memahami tindakan-tindakan pada subjek dan objek yang diteliti melalui teknik-teknik penelitian kualitatif seperti wawancara secara mendalam dan respon siswa terhadap pembelajaran online. Sebab untuk mendapatkan hasil dari penelitian yang mendalam tentang efektivitas pembelajaran online di MTs. Nurul 
Jadid akan lebih baik jika dilakukan dengan cara pemberian angket \& kegiatan wawancara.

Sumber data adalah segala yang berkaitan dengan penelitian dalam mendapatkan data atau dokumen penting. Moleong (20014:157) menjelaskan sumber data untuk jenis kualitatif berupa aktivitas dan kata-kata, dokumen merupakan tambahan. kegiatan wawancara atau pemberian angket merupakan data yang dikumpulkan langsung di lapangan oleh yang bersangkutan (Hasan, 2002:82). Sementara Pengumpulan data merupakan salah satu kegiatan penunjang pelaksanaan kegiatan penelitian, dimana pengumpulan data dilakukan untuk menentukan berhasil tidaknya suatu penelitian. Prosedur pengumpulan data yang digunakan peneliti antara lain: 1) Wawancara, wawancara merupakan pemberian pertanyaan ke responden, dan merekam/mencatat segala jawabanjawabannya. Wawancara digunakan untuk mengetahui efektivitas pembelajaran online dalam pembelajaran matematika di MTs. Nurul Jadid. 2) Angket, rangkaian bentuk pertanyaan yang diberikan kepada responden untuk memperoleh data-data terkait suatu penelitian. Sementara angket yang digunakan adalah angket terbuka, dengan pertanyaan telah dibuat dan disiapkan oleh peneliti. Responden akan leluasa, sehingga jawaban tidak dibatasi.

\section{HASIL DAN PEMBAHASAN}

Berdasarkan kegiatan wawancara dan pemberian angket untuk mengetahui respon siswa diuraikan berikut ini.

1. Kefektivan Pembelajaran Online Pembelajaran Matematika

Berdasar hasil kegiatan wawancara dengan kepala sekolah dan guru matematika MTs. Nurul Jadid yang menyatakan:

Kepala Sekolah "Pembelajaran online di MTs. Nurul Jadid dapat dikataklan cukup efektif karena dalam kegiatan belajar cukup lancar, kegiatan belajar antara siswa dengan gruи cukup baik. Siswa juga senang dalam belajar online. Namun ada catatan yang perlu diperbaiki yaitu terkait kendala jaringan. Terkadang ada beberapa siswa yang tidak hadir dikarenan sinyal kurang baik, ada juga dalam kegiatan belajar siswa tiba-tiba 
menghilang dari kegiatan belajar online dan ketika di konfirmasi ke siswa sinyal internet atau data sudah habis."

Guru Pelajaran Matematika "Siswa sangat terlibat dalam kegiatan belajar. Siswa yang biasanya diam di kelas juga terlibat dalam belajar secara online ini."

2. Kelebihan dan kekurangan pembelajaran online dalam pembelajaran Matematika Berikut pernyataan kepala sekolah dan guru matematika terkait kelebihan Pembelajaran online.

Kepala Sekolah "Kelebihan dalam pembelajaran online banyak sekali salah satunya tidak terbatas waktu artinya siswa dan guru bisa belajar darimana saja. Selanjutnya siswa yang biasanya kurang aktif di kelas pada saat belajar ofline menjadi aktif pada saat belajar online.kalau kekurangaannya sinyal di daerah tidak menentu terkadang sinyal kurang bagus sehingga menyebabkan pembelajaran online kurang baik.komunikasi terputus dan sebagainya."

Guru Matematika "siswa yang semula pendiam di kelas bisa menjadi berani dalam menanggap. Motivasi belajar siswa juga bagus karena pembelajaran online merupakan pembelajaran yang baru bagi siswa dan semoga kedepannya lebih baik lagi dari segistrategi pembelajarannya ataupun aplikasi yang dapat digunakan oleh guru."

Sementara untuk kekurangan dalam pembelajaran matematika sebagai beikut.

Kepala sekolah "Jika terkait dengan perbaikan tentu yang pertama adalah kualitas jaringan dan data untuk siswa dan guru. Selanjutnya da media sebagai bahan informasi kepada siswa agar proses pembelajaran online erjalan dengan lancar." Guru Matematika "kekurangaannya sinyal siswa terkadang terputus-tupus sehingga komunikasi jadi terhambat dan memakan waktu. Siswa juga ada yang ijin lewat sms karena 
tidak bisa mengikuti kegiatan belajar mengajar karena tidak memiliki handphone gadget."

3. Bidang yang perlu diperbaiki dalam proses pembelajaran online

Berkaitan bidang yang perlu ada perbaikan dalam proses pembelajaran online di MTs. Nurul Jadid, berikut wawancaranya:

Kepala sekolah "Perbaikan tentu yang pertama adalah kualitas jaringan dan data untuk siswa dan guru. Selanjutnya adalah media sebagai bahan informasi kepada siswa agar proses pembelajaran online berjalan dengan lancar."

Guru Matematika “dari saya, sebaiknya siswa lebih diberikan media hidup seperti mengamati video. Namun terkendala kemampuan guru membuat video pembelajaran."

4. Respon Siswa Dalam Kegiatan Pembelajaran Online

Berdasarkan perhitungan respon siswa terhadap angket yang diberikan menunjukkan bahwa siswa sangat senang dengan kegiatan pembelajaran online. Dalam kegiatan aktivitas pembelajaran online, siswa sangat antusias dan bersemangat dalam mengikuti kegiatan pembelajaran online. Hal ini juga dikarenakan siswa merespon bahwa pembelajaran online menarik. Ada beberapa siswa yang merespon menglami kesulitan dalam pembealajaran online. Salah satu yang menjadi kendala terbesar siswa adalah sinyal yang menjadikan kegiatan pembelajaran online kurang maksimal bagi siswa tersebut. Dalam memahami pembelajaran online siswa tidak mengalami kesulitan dalam mempelajari pelajaran matematika. Hal ini dikarenakan siswa memperhatikan penjelasan guru pada saat menjelaskan topik pada mata pelajaran matematika. Dengan pembelajaran online penyajian materi pelajaran juga menjadi menarik.

Dengan pembahasan diatas menunjukkan bahwa pembelajaran online di MTs. Nurul Jadid cukup efektif. Hal tersebut dikarenakan kegiatan pembelajaran online di MTs. Nurul Jadid pemberian materi, pemberian tugas dan pengumpulan tugas terlaksana dengan baik. Hal ini ditunjukkan dengan adanya 1) siswa yang semula pendiam atau pemalu menjadi percaya diri. hal ini dapat disebabkan karena siswa lebih berani karena berhadapan dengan guru dan teman-temannya melalui 
media handphone. Hal ini sangat bagus untuk melaltih siswa lebih percaya diri lagi pada saat kegiatan tatap muka diberlakukan kembali; 2) Lebih efektif dalam segi tempat dan waktu. Pelaksanaan pembelajaran dapat dilakukan oleh siswa dari mana saja. Sehingga hal ini tidak menjadi beban bagi siswa dalam melaksnakan kegiatan belajar mengajar; 3) ketergantungan siswa pada guru berkurang. Hal ini disebabkan karena siswa dapat menemukan informasi materi pelajaran tidak hanya pada guru saja, siswa dapat menemukan informasi lebih dari media internet yan gmemiliki berbagai informasi di dalamnya.

Namun juga terdapat problem yang dihadapi saat pembelajaran online antara lain: 1) perlunya adaptasi dari guru dalam pengelolaan pembelajaran. Hal ini dikarenakan yang berubahnya proses belajar dari tatap muka menjadi online. Tentu dengan adanya dampak perubahan belajar mengajar ini menjadi kerugian besar bagi guru karena dalam belajar menggajarnya menjadi kurang maksimal. Namun dalam hal kegiatan pembelajaran online siswa aktif terlibat dalam proses belajar. Kegiatan pembelajaran online di MTs. Nurul Jadid juga memiliki kendala bagi siswa dan guru yaitu sinyal di tempat daerah siswa tidak begitu bagus. Sehingga dalam pelaksanaannnya pembelajaran online ini terdapat beberapa siswa yang tidak dapat mengikuti kegiatan pembelajaran online ataupun telat dalam mengumpulkan tugas yang telah diberikan oleh guru.

Berdasarkan uraian respon siswa, menunjukkan secara keseluruhan pembelajaran online sangat diminati oleh siswa. Walaupun ada beberapa kendala yang dialami oleh sebagian siswa, namun siswa sangat senang dengan kegiatan pembelajaran online. Siswa juga terlihat sangat antusias dalam pembelajaran online. Hal ini menunjukkan bahwa siswa memiliki motivasi dan semangat yang tinggi untuk belajar matematika secara online. Sementara berdasarkan persentase respon siswa menunjukkan perolehan nilai sebesar $68,23 \%$ yang berdasarkan kategorinya berada pada kategori kuat. Artinya bahwa siswa sangat senang dengan pembelajaran online yang dilaksanakn di MTs. Nurul Jadid ini. 


\section{SIMPULAN}

Kefektifan pembelajaran matematika online di MTs. Nurul Jadid dapat dikatakan cukup efektif. Hal ini berdasarkan data yang telah diuraikan sebelumnya yaitu sebagai berikut. 1) Kegiatan pembelajaran online di MTs. Nurul Jadid yaitu pemberian materi, pemberian tugas dan pengumpulan tugas. Tentu dengan adanya dampak perubahan belajar mengjar ini menjadi kerugian besar bagi guru karena dalam belajar menggajarnya menjadi kurang maksimal. Namun dalam hal kegiatan pembelajaran online siswa aktif terlibat dalam proses belajar. Hal ini juga terjadi pada siswa yang sebelumnya tidak aktif pada saat kegiatan belajar secara tatap muka, namun pada pembelajaran online ini aktif. 2) Berdasarkan kelebihan pembelajaran online, siswa yang pendiam atau pemalu lebih percaya diri. hal ini dapaat disebabkan karena siswa lebih berani karena berhadapan dengan guru dan teman-temannya melalui media handphone. Pembelajaran lebih efektif dalam segi tempat dan waktu. Pelaksanaan pembelajaran dapat dilakukan oleh siswa dari mana saja. ketergantungan siswa pada guru berkurang. Hal ini disebabkan karena siswa dapat menemukan informasi materi pelajaran tidak hanya pada guru saja, siswa dapat menemukan informasi lebih dari media internet yan gmemiliki berbagai informasi di dalamnya. Sementara berdasarkan kekurangannya, sinyal menjadi kendalan sebagian besar siswa. Namun secara keseluruhan pembelajaran online berdampak positif pada kegiatan pembelajaran siswa. 3) Persentase repon siswa terhadap pembelajaran online mencapai $68,23 \%$. Nilai ini berada pada kategori kuat dengan maksud bahwa siswa sangat senang dan antusias dengan pembelajaran online yang dilaksanakan di MTs. Nurul Jadid.

\section{REFERENSI}

Enriquez, M. A. S. 2014. Students' Perceptions on the Effectiveness of the Use of Edmodo as a Supplementary Tool for Learning. DLSU Research Congress. https://doi.org/10.1017/CBO9781107415324.004.

Hasan, M. Iqbal. 2002. Pokok-Pokok Materi Metodologi Penelitian dan Aplikasinya. Jakarta: Ghalia Indonesia.

Iftakhar, S. 2016. GOOGLE CLASSROOM: WHAT WORKS AND HOW? Journal of Education and Social Sciences. 
Kumar, V., \& Nanda, P. 2018. Social Media in Higher Education. International Journal of Information and Communication Technology Education. https://doi.org/10.4018/ijicte.2019010107.

Mandagi, M. O., \& Degeng, I. N. S. 2019. Model dan Rancangan Pembelajaran. CV. Seribu Bintang.

Moleong, L. 2014. Metodologi Penelitian Kualitatif. Bandung: PT Remaja Rosdakarya.

Sicat, A. S. 2015. Enhancing College Students' Proficiency in Business Writing Via Schoology. International Journal of Education and Research.

Slavin, R E. 2009. Cooperative Learning. Bandung : Nusa Media.

So, S. 2016. Mobile instant messaging support for teaching and learning in higher education. Internet and Higher Education. https://doi.org/10.1016Zj.iheduc.2016.06.001 .

Sutopo. 2006. Metodologi Penelitian Kualitatif. Surakarta: UNS. 